\title{
De zorg voor kinderen met epilepsie
}

Dit themanummer laat zien dat we best trots mogen zijn op het onderzoek dat in Nederland plaatsvindt op het gebied van epilepsie bij kinderen. Dat onderzoek heeft zich in de afgelopen tien jaar met name geconcentreerd in samenwerkingsverbanden van de beide epilepsiecentra met enkele universitair medische centra. De vraag is of de zorg die we in ons land aan kinderen met epilepsie bieden, daarmee gelijke tred houdt.

In Nederland worden kinderen met mogelijke epileptische aanvallen voor het merendeel naar de regionale kinderarts verwezen. De rol van de neuroloog in datzelfde ziekenhuis beperkt zich over het algemeen tot de beoordeling van het EEG. Een gezamenlijk spreekuur van kinderarts en neuroloog is door de huidige DBC (diagnosebehandelcombinatie)-structuur niet haalbaar. Bij twijfel over de diagnose of onvoldoende effectiviteit van een eerste ingezet anti-epilepticum vindt verwijzing plaats naar een kinderneuroloog in een universitair medisch centrum. Een deel van de kinderen komt daarna terecht bij de kinderneuroloog in een epilepsiecentrum. Het hoeft geen betoog dat een dergelijk soms langdurig traject met diverse behandelaars in verschillende ziekenhuizen onwenselijk is. Afgezien van de kwaliteit van de zorg voor kinderen met epilepsie kunnen er ook kritische kanttekeningen geplaatst worden. Die kanttekeningen hebben deels betrekking op de lange tijd die soms verloopt alvorens het kind met epilepsie de dokter met voldoende kennis van zaken bereikt. Daarnaast blijkt dat ouders vaak onvoldoende steun ondervinden bij het organiseren van adequate psychosociale zorg en schoolvoorzieningen.

De vraag is op welke manier we de zorg zo kunnen organiseren dat in een vroeg stadium de voor het kind beste noodzakelijke expertise betreffende diagnostiek en behandeling beschikbaar is en tevens adequaat wordt ingespeeld op vragen van ouders hoe om te gaan met een kind met epilepsie, welke veiligheidsmaatregelen nodig en zinvol zijn en hoe de emotionele en cognitieve ontwikkeling gemonitord en gestimuleerd kunnen worden. Daarnaast wordt verwacht dat dit op een kosteneffectieve wijze gebeurt en zo dicht mogelijk bij de woonplaats van de patiënt. Om dit te bereiken is in 2012 in het Martini
Ziekenhuis in Groningen door kinderneuroloog Nynke Doornebal in samenwerking met de afdeling kinderneurologie van het Universitair Medisch Centrum Groningen (UMCG) gestart met een aanvalspolikliniek voor kinderen uit Noord-Nederland (Roelfsema et al., Epilepsie,

Periodiek voor professionals, jaargang 17 , nummer 2, juni 2019). Huisartsen en kinderartsen in heel Noord-

Nederland kunnen kinderen verwijzen met aanvallen waarvan de origine niet duidelijk is of waarvan een epileptische genese wordt vermoed maar de aanvalsclassificatie problemen oplevert. Tijdens deze polikliniek worden de kinderen gezien en wordt aansluitend een EEG gemaakt. $\mathrm{Na}$ een daarop volgend multidisciplinair overleg worden de bevindingen en een vervolgplan met de ouders besproken. Aanvankelijk waren bij dit multidisciplinair overleg naast de kinderneuroloog en klinisch neurofysioloog ook een klinisch geneticus en epilepsieconsulent aanwezig. In de loop der jaren werden daar ook een kinderneuropsycholoog en een kinderneuroloog van SEIN bij betrokken. Deze aanvalspolikliniek blijkt niet alleen zeer effectief en patiëntvriendelijk, maar brengt ook de professionals, die verantwoordelijk zijn voor de epilepsiezorg in de regio, bij elkaar voor uitwisseling van gedachten.

Onlangs heeft minister Bruins (Minister voor Medische Zorg en Sport) zijn visie op het medisch zorglandschap uiteengezet. Hij benadrukte daarbij dat door maatschappelijke veranderingen een andere organisatie van de zorg wordt gevraagd, waarin multidisciplinaire samenwerking en samenwerking in netwerken steeds belangrijker worden. Laten wij deze handschoen oppakken en met elkaar kijken op welke manier we gezamenlijk de zorg voor kinderen met epilepsie ook toekomstbestendig kunnen maken.

Lees het actuele overzicht van congressen over epilepsie.

\section{Kijk voor meer informatie op www.epilepsieliga.nl.}

